\title{
The Role of GTL Technology as an Option to Exploit Natural Gas Resources
}

\author{
Maha Abdel-Kreem, M. Bassyouni, Shereen M.-S. Abdel-Hamid and Hussein Abdel-Aal*
}

Higher Technological Institute, Tenth of Ramadan, Egypt

\begin{abstract}
Large amounts of global sources of remote natural reserves gas are identified along with the main objective to allow energy contained in to be moved economically to the market. The current options that are adopted to export natural gas are basically two:-

1. To liquefy the gas and ship it as LNG (Liquefied Natural Gas).

2. To convert it to bulk petrochemicals in particular methanol or ammonia and other down-stream products.

The last approach represents relatively small usage of the gas with limited markets. Chemical conversion before transportation of natural gas to liquid (GTL), using Fisher-Tropsch process offers an attractive alternative to unlock remote sources of natural gas. It is reported to be most promising on the basis of its current level of development and its potential future improvements.

The two main components of Fisher-Tropsch process are carefully examined: synthesis gas generation and its subsequent conversion to clean petroleum fuel. Different methods of producing synthesis gas are described. These include: steam reforming, non catalytic partial oxidation (NCPO), auto thermal reforming (ATR) and combined reforming. Chemical reactions underlying the Fisher-Tropsch process are presented with trends of developments in the GTL technology.

Commercial applications of GTL technology worldwide are cited, especially in some Arab countries. The positive impact of GTL on the environment is emphasized because of two reasons: $1^{\text {st }}$ the clean-burning properties of the produced diesel fuels, $2^{\text {nd }}$ converting natural gas to liquid allows oil producers to utilize the natural gas that would otherwise be flared and pollute the atmosphere.
\end{abstract}

\section{INTRODUCTION}

New technology is being developed and applied to convert natural gas to liquids, known as GTL. The key influences on the competitiveness of the GTL approach are the following factors:-

1. Cost of capital investment.

2. Operating costs of the plant.

3. Cost of feed stock.

4. The anticipated scale of production and the ability to achieve high utilization rates in production.

GTL not only adds value by utilizing remote natural gas, but capable of producing superior products that can be sold or blended into refinery products.GTL, however is not competitive against conventional oil production unless the gas has a low opportunity value and not readily transported. The difficulty of moving remote natural gas to the market in a profitable way can be comprehended if we know that many important gas fields are very far from the main international market. The following are some specific examples:

- Sakhalin area (Russia) is about 3,000 km from Tokyo (Japan).

*Address correspondence to this author at the Consultant \& Emeritus Professor of Chemical Eng/Petroleum Refining, NRC Address: 18 Jeddah Street, Doki, Cairo, Egypt; Tel: + 202 3499028; Mobile: +2010 5151806; E-mail: habdelaal@link.net
- Bonny area (Nigeria) is about $8,000 \mathrm{~km}$ from Rotterdam (The Netherlands).

- Abu Dhabi fields ( U.A.R.) are about 11,000 km from both Rotterdam and Tokyo.

- In addition, large gas reserves exist in Qatar, Iran, Saudi Arabia, Canada and Alaska.

The world's proven gas reserves are estimated at a value of 6000 trillion cubic feet (t c f); while the potential reserve is reported to be around 13,000 $\mathrm{t} \mathrm{c}$ f. Only a small fraction of the world marketed production of natural gas is internationally traded today. Of the proven and potential gas reserve, up to $80 \%$ are too far from large markets to be transported by pipeline. Some remote gas reserves are shipped as LNG (Liquefied Natural Gas) using cryogenic liquefaction which requires expensive insulated and pressurized vessels. Other option is to convert natural gas into chemical products such as methanol which is exported using conventional tankers different kind of technology for converting hydrocarbon gases to liquids, called gas-to-liquid (GTL) is on the verge of changing the exploitation of remote reserves of natural gas in the world. Many large oil and gas companies are developing expertise in this new field. A few already have commercially operating plants and many have initiated pilot projects.In summary, the conversion of remote natural gas reserves to liquid products to be shipped by tankers is illustrated in Fig. (1). 


\section{Conversion of Remote Natural Gas to Liquid Products, to be transported by tankers can be accomplished by one of the following methods:}

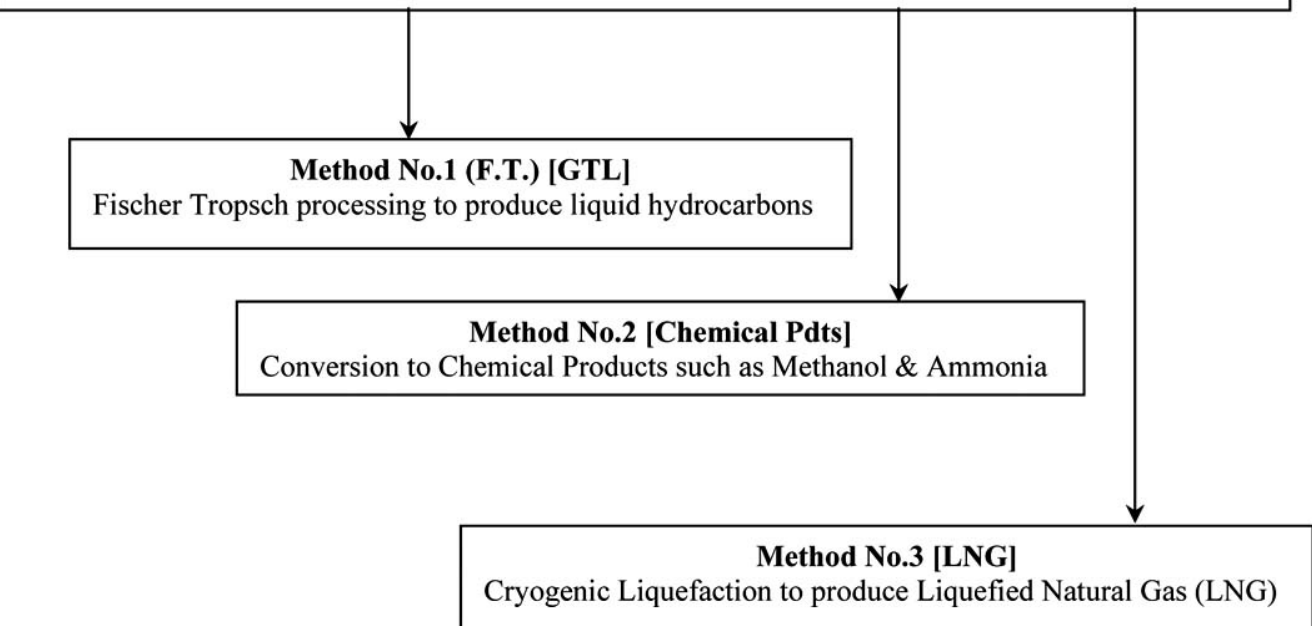

Fig. (1). Alternatives for shipping remote reserves of natural gas as liquid.

\section{GTL TECHNOLOGY}

The primary objective of GTL technology is to convert natural gas into clean petroleum products. In principle, there are two broad technologies to convert natural gas to liquids:-

\section{a) "Syncrude"- The Direct Approach to Convert Natural} Gas into what is known as Synthetic Crude

The direct conversion of natural gas (typically from 85 to $90 \%$ methane), eliminates the cost of producing synthesis gas as intermediate step, but it involves high activation energy and is difficult to control .Several direct conversion processes have been launched, but none have been commercialized; being economically unattractive.

\section{b) Synthesis Gas (Syngas): the Indirect Conversion of} Natural Gas to Liquids

Instead of carrying a heavy load in one trip, divide it and make two trips. In principle, the process of converting natural gas into clean petroleum liquids involves basically two steps:

$1^{\text {st }} \quad$ Generation of synthesis gas

$2^{\text {nd }}$ Conversion of synthesis gas to petroleum fuels via Fisher-Tropsch (F-T) synthesis

Converting gases to liquid, in its general term, i.e. GTL, could imply the following two options:-

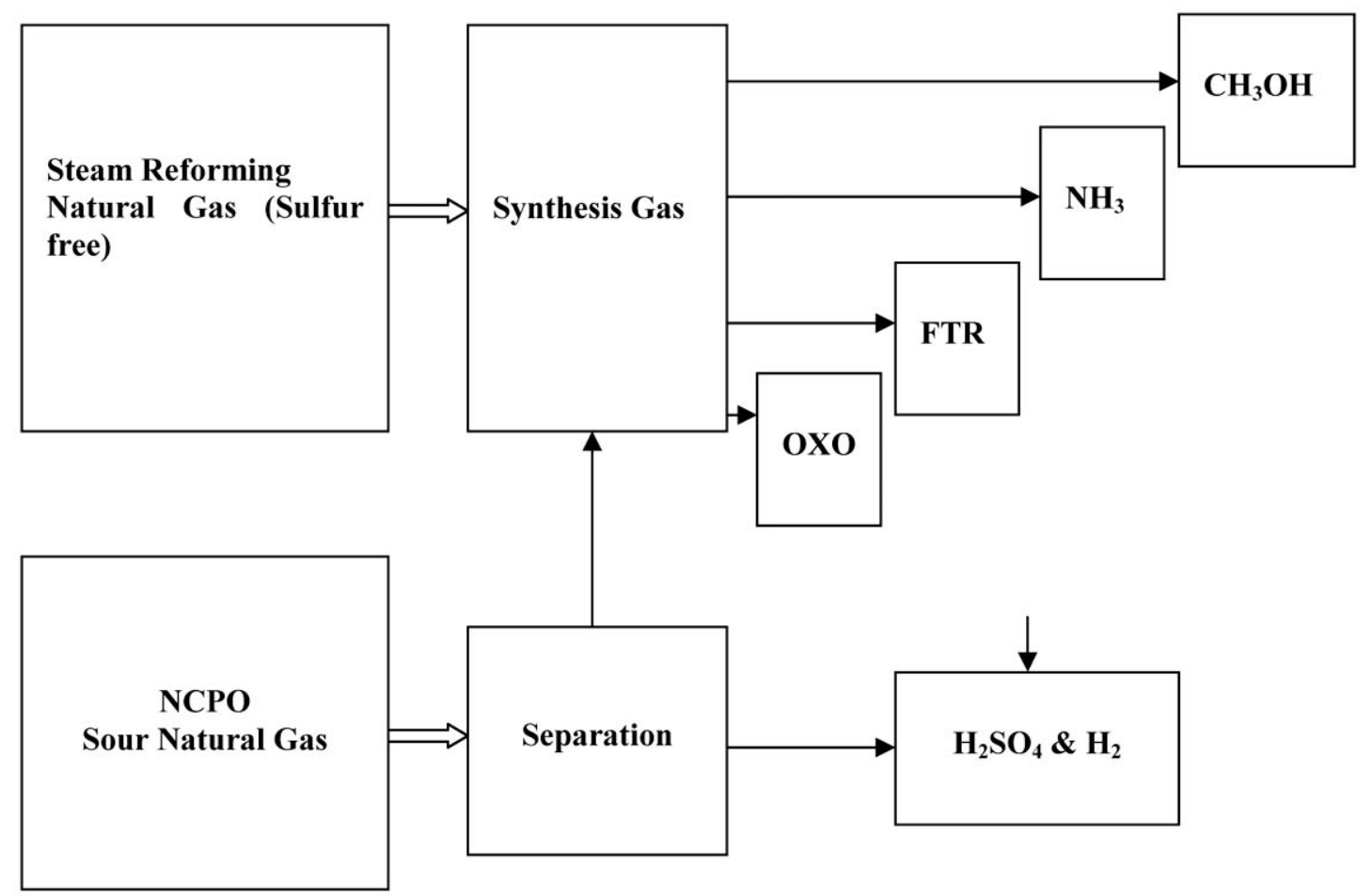

Fig. (2). Possible options for GTL products obtained from natural gas as a feed stock. 


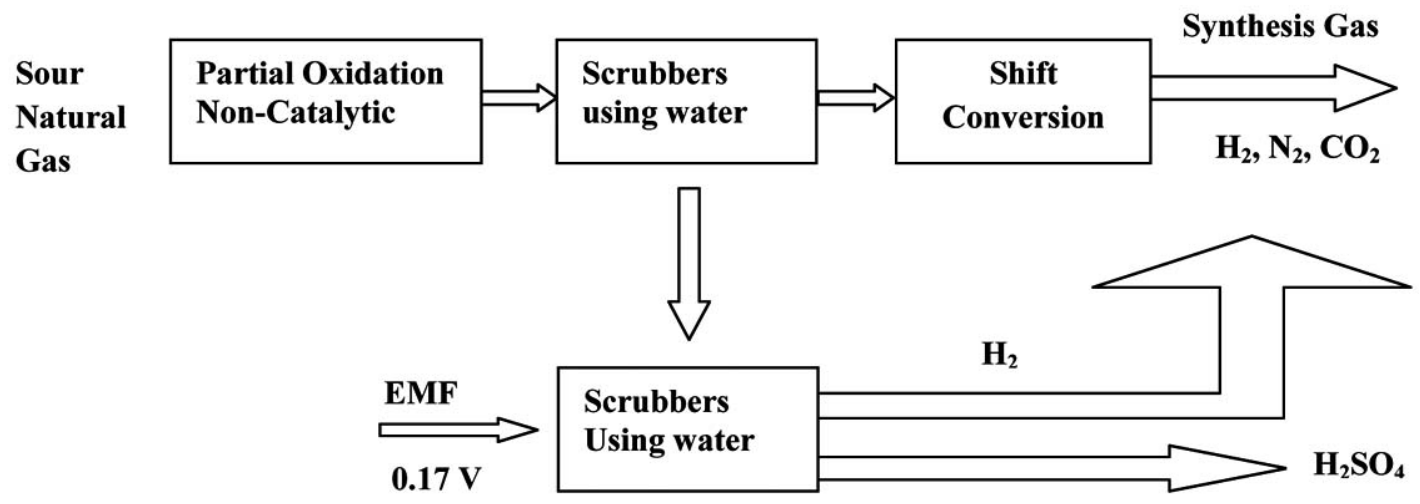

Fig. (3). Production of synthesis gas from sour natural gas (NPO).

\section{First}

GTL products obtained from hydrocarbons recovered from natural gas- this may involve the production of high octane gasoline fuels by alkylation and polymerization processes. In addition, the application of fuel-cells using methane as a feed stock produces energy plus water as products.

\section{Second}

GTL products obtained from natural gas as a feed stock, as shown in Fig. (2). This may involve producing synthesis gas (referred to as "syngas" which is a mixture of $\mathrm{H}_{2}$ \& $\mathrm{CO}$ ) from sulfur-free feed using one of the following four wellestablished processes:-

1. Steam reforming (SR).

2. Catalytic partial oxidation (CPO).

3. Auto-thermal reforming (ATR).

4. Combined or two-step reforming (TSR).

When handling sour natural gas (gas containing sulfur compounds), the non-catalytic partial oxidation process (NCPO) is recommended for the production of syngas, along with sulfuric acid as presented in Fig. (3) [1,2].

\section{GTL TECHNOLOGY USING FISHER-TROPSCH PROCESS}

The discovery of Fisher Tropsch chemistry dates back to the 1920s .Its development has been for strategic rather than economic reasons as in Germany during World War II and in South Africa during the apartheid era.

During the last years, there has been a renewed interest to use Fischer-Tropsch technology to convert natural gas to liquid (GTL). The following are some of the factors that motivated this new trend:-

1. The discovery of huge reserves of natural gas, mostly remote or stranded reserves; and the need to mobilize it to the international market.

2. Environmental restrictions against flaring associated gas.

3. Developments in the technology of the process along with improvements in the cost-effectiveness of converting the gas to liquid.
The conversion process, in general, encompasses the following three basic stages:-

- Generation of syngas.

- Conversion of syngas to petroleum products.

- Hydro-processing to upgrade the produced products into finished ones.

These stages are schematically illustrated in Fig. (4).

\section{GENERATION OF SYNTHESIS GAS}

\section{Reforming (Strongly Endothermic)}

$\mathrm{CH}_{4}+\mathrm{H}_{2} \mathrm{O} \leftrightarrow \mathrm{CO}+3 \mathrm{H}_{2}$

$\mathrm{CH}_{4}+\mathrm{CO}_{2} \leftrightarrow 2 \mathrm{CO}+2 \mathrm{H}_{2}$

Combustion (Strongly Exothermic)

$2 \mathrm{CH}_{4}+\mathrm{O}_{2} \leftrightarrow 2 \mathrm{CO}+4 \mathrm{H}_{2}$

$\mathrm{CH}_{4}+2 \mathrm{O}_{2} \leftrightarrow \mathrm{CO}_{2}+2 \mathrm{H}_{2} \mathrm{O}$

\section{Shift Conversion (Midly Exothermic)}

$\mathrm{CO}+\mathrm{H}_{2} \mathrm{O} \leftrightarrow \mathrm{CO}_{2}+\mathrm{H}_{2}$

Carbon

$$
\begin{aligned}
& \mathrm{CH}_{4} \leftrightarrow 2 \mathrm{H}_{2}+\mathrm{C} \\
& 2 \mathrm{CO} \leftrightarrow \mathrm{CO}_{2}+\mathrm{C}
\end{aligned}
$$

\section{a) Steam Reforming}

The first stage is the reaction between the hydrocarbons; exemplified with methane and steam:-

$\mathrm{CH}_{4}+\mathrm{H}_{2} \mathrm{O} \rightarrow \mathrm{CO}+3 \mathrm{H}_{2}$ followed by:

$\mathrm{CO}+\mathrm{H}_{2} \mathrm{O} \rightarrow \mathrm{CO}_{2}+\mathrm{H}_{2}$

The total overall reaction may be represented by:

$\mathrm{CH}_{4}+2 \mathrm{H}_{2} \mathrm{O} \rightarrow \mathrm{CO}_{2}+4 \mathrm{H}_{2}$

Inspection of equation (1) shows that the reaction conditions should be as follows:- Pressure is adverse, since two molecules of reactant give four molecules of product. Excess steam will tend to push equilibrium in favor of $\mathrm{CO}$. The reaction is highly exothermic and equilibrium moves favorably with rise of temperature. In practice, the theoretical equilibrium is approached by using catalysts. The most common is nickel promoted with magnesia or alumina, mounted on an 


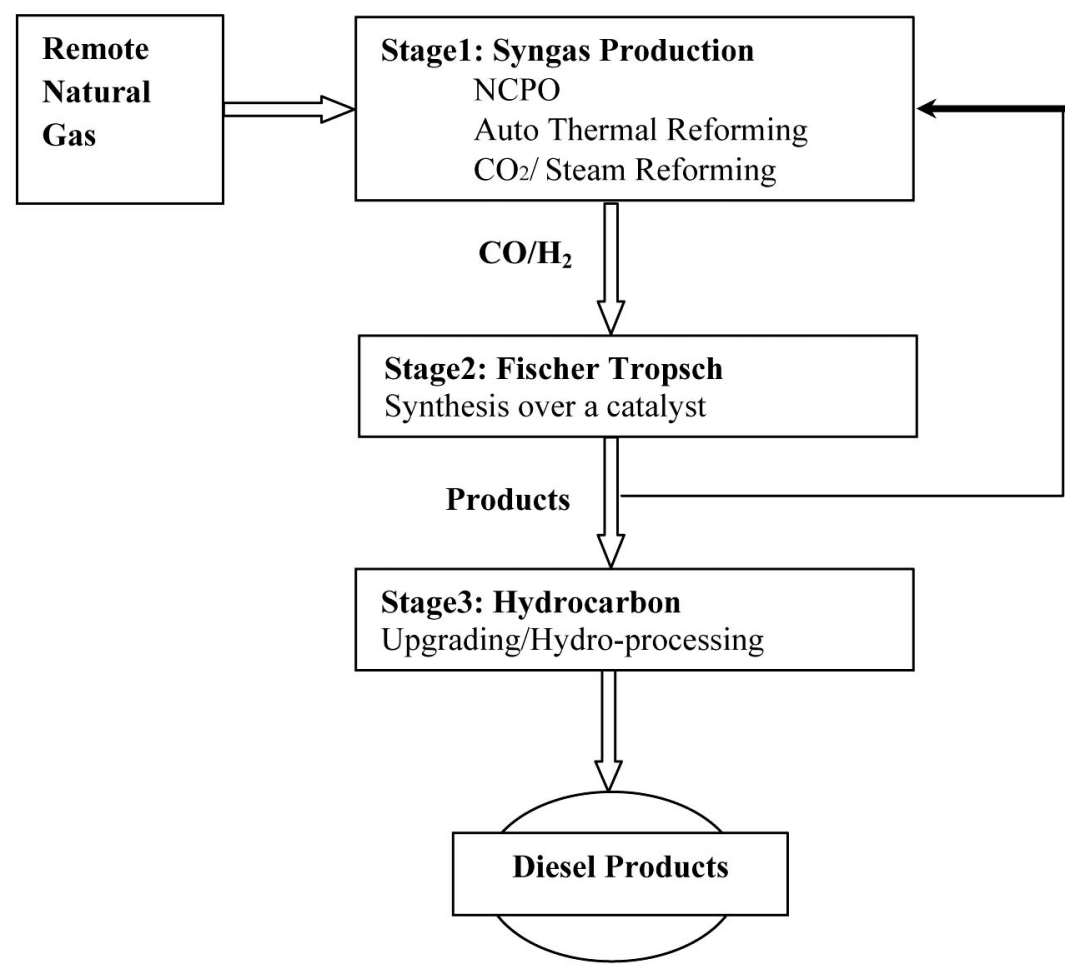

Fig. (4). The three basic stages in F-T process.

inert support. Steam reforming may be considered to generate syngas under the following conditions:- A relatively small GTL plant (capacity is below 10, $0000 \mathrm{bbl} / \mathrm{day}$ ). Additional hydrogen could be used to produce methanol or/ and ammonia as co-product. The source of natural gas has a high $\mathrm{CO}_{2}$ content. Water is available at a low cost.

\section{b) Non-Catalytic Partial Oxidation (NCPO)}

The non- catalytic partial combustion of methane produces syngas with $\mathrm{H}_{2} / \mathrm{CO}$ ratio $<2$, which is close to the optimum needed by Fisher-Tropsch process .This low ratio results from the very little steam that is used in the process. Due to the absence of catalysts, the reformer operates at an exit temperature of 1400 degree $\mathrm{C}$. This high temperature along with absence of catalysts could lead to:

1. The formation of soot.

2. Higher oxygen consumption.

\section{c) Auto-Thermal Reforming (ATR)}

Unlike NCPO, auto thermal reforming uses a catalyst for reforming in the presence of steam and oxygen. Due to the milder operating conditions (exit temperature about 1000 degree $\mathrm{C}$ ) and the use of steam ( $\mathrm{S} / \mathrm{C}$ ratio about 1.3$)$, the synges is soot free. However, at this $\mathrm{S} / \mathrm{C}$ ratio, syngas produced will have a $\mathrm{H}_{2} / \mathrm{C}$ ratio about 2.5 , higher than what is needed by Fisher-Tropsch.

\section{d) Combined Reforming or Two-Step Reformer (TSR)}

Combining a steam reformer and an auto thermal reformer will bring in better energy utilization than can be achieved with either one. Although less expensive than steam reforming on its own, this type of reforming is more expensive than auto thermal reforming. The choice between combined reforming on one hand and auto thermal reforming, on the other side will depend on the cost of natural gas.

\section{CONVERSION OF SYNTHESIS GAS TO PETRO- LEUM PRODUCTS}

The conversion of syngas to liquid hydrocarbons is a chain-growth chemical reaction of carbon mono-oxide and hydrogen on the surface of a heterogeneous catalyst. To state differently, the reaction could be described as the catalytic condensation of carbon monoxide and hydrogen to give high molecular weight hydrocarbons with the elimination of water. The main reaction is represented by:-

$$
(2 \mathrm{n}+1) \mathrm{H}_{2}+\mathrm{n} \mathrm{CO} \rightarrow \mathrm{H}-\left(\mathrm{CH}_{2}\right)_{\mathrm{n}^{-}}+\mathrm{H}_{2} \mathrm{O}(\mathrm{g})
$$

The "carbon number" of hydrocarbons produced by F-T reaction always has a wide range; "n" ranges from 1 to an upper limit of 50, 70 or even 100 [3]. The hydrocarbons obtained are mixtures of paraffin and olefins. They include LPG, naphtha, diesel, heavy gas oil (Wax).

The ratio depends on two parameters:

1. The reaction conditions inside the reactor $(\mathrm{T} \& \mathrm{P})$.

2. The ratio of carbon mono-oxide to hydrogen in the syngas.

Carbon dioxide formation represents wastage of the valuable carbon monoxide. It can be avoided by suitable choice of catalyst. On the other hand, methane formation could be minimized by careful choice of reaction conditions. The two vital factors for the successful operation of the Fisher- 
Table 1. GTL Plants Corresponding to F-T Process

\begin{tabular}{|c|c|c|c|c|}
\hline Name of Comp. \& Locat. & Need of $\mathbf{O}_{2}$ & Syngas Ref. & FT Syngas Cat. & Capacity (bbl/day) \\
\hline \hline JOGMEC/Japan & No & Tubular & Slurry bed (Co) & 7 (pilot unit) \\
\hline Sasol /South Africa & Yes & ATR & Slurry bed (Co) & $17,000(2$ units) \\
\hline Shell/ Malaysia & Yes & NCPO & Slurry bed (Co) & $200($ demonstration) \\
\hline ExxonMobil/USA & Yes & ATR & Slurry bed (Co) & $400($ demonstration) \\
\hline Conoco/USA & Yes & SPO & Slurry bed (Co) & $300($ demonstration) \\
\hline BP/USA & Yes & Compact reformer & & \\
\hline
\end{tabular}

ATR: Auto-thermal reformer, NCPO: non-catalytic partial oxidation, CPO: catalytic partial oxidation.

Tropsch process are: 1-Accurate control of temperature 2Provision of an active and long-lived catalyst.

\section{HYDRO-PROCESSING}

This is the final step in shaping up the final products. The wax and the hydrocarbon condensate produced by the Fisher-Tropsch process is predominantly linear paraffin with a small fraction of olefins and oxygenates. By using hydrogen, the main chemical reactions taking place in hydroprocessing are:

1. Hydrogenation of the olefins and oxygenates.

2. The hydro cracking of the wax to naphtha and diesel.

Hydro processing can be done at relatively mild conditions. In the design of hydrocracker, a balance must be found between the per-pass conversion, diesel selectivity and diesel properties. The higher the per pass conversion, on one hand, the smaller the cracker will be due to less recycle of material back to the cracker. This will be however, at the expense of the diesel selectivity, since over-cracking of the liquid to gases will occur.

Trends in the Development of GTL Technology and Commercial Applications

Table 1 shows a survey of the existing GTL plants is given first, to indicate the most recent trends taking place in synthesis gas production and the corresponding F-T process $[4,5]$ :

Today, South Africa is the world's leading producer of liquid fuel from natural gas (GTL Technology).Sasol is a synfuel technology supplier established to provide petroleum products in coal-rich, but oil-poor South Africa. The firm has built a series of Fisher-Tropsch coal-to-oil plants. It has developed the world's largest synthetic fuel project, the Mossgas complex at Mossel Bay in South Africa that was commissioned in 1993.

Table 2 shows a list of some major companies with estimated capacities of existing and potential GTL plants that they undertake in different parts of the world [6].

\section{CONCLUSIONS AND RECOMMENDATIONS}

1. Fisher-Tropsch technology plays a key role in the GTL conversion process. It offers an effective means to use untapped natural gas resources and a diversification of fuel resources by ensuring substitutes for crude oil. GTL not only add value, but capable of producing products that could be sold or blended into refinery stock as superior products with clean-burning properties. Diesel fuels produced by the process have an energy density comparable to conventional diesel, but with higher cetane number. This should be considered the most significant advantage of GTL process.

2. GTL process needs low-cost natural gas as a feed stock; less than $\$ 1.0$ per million Btu to compete with traditional diesel fuels. Some sources of remote natural gas called "stranded gas", that are not otherwise economically available will be ideally suited for this process. Examples are: Alaska and Qatar. GTL in operation today, converts 10,000 cubic feet (286 cubic meters) of natural gas into slightly more than one barrel of liquid (synthetic fuel).

3. While the cost of producing GTL fuel has been declining as a result of using better catalysts, scale up and plant design, the transport and distribution costs are slightly higher compared to refinery-produced fuels. Research and development is focused on reducing costs further. Examples are cited for Co catalysts as follows: Increasing the catalyst life by making it more resistant to irreversible sulfur poisoning. Changing the selectivity dependency on the $\mathrm{H}_{2} / \mathrm{CO}$ ratio to such an extent that high diesel yields can be obtained at $\mathrm{H}_{2} / \mathrm{CO}$ ratios similar to the usage ratio.

4. Converting natural gas to liquid fuel benefits the environment in producing clean fuels, Fisher-Tropsch process manufactures diesel with zero sulfur. In addition, GTL encourages oil producers to utilize the associated gas produced in the oil fields and not to be flared.

5. Associated natural gas could be converted to petroleum fuels and blended with heavy crude oils. This will upgrade the quality of the crude and cut, at the same time, the expenses incurred in collecting and transporting the associated gas.

6. The composition of the HC feed stock sets the preferred conversion routes for the production of liquid transportation fuels- eg: Gasoline or Middle Distillate Fuels (kerosene/gas oil): when the $\mathrm{C} / \mathrm{H}$ ratio of feed stocks and products are well matched; as with the case: coal $\rightarrow$ aromatic gasoline, and with natural gas $\rightarrow$ middle distillates, then a relatively high 
Table 2. Some Major Companies with Estimated Capacities of Existing and Potential GTL Plants

\begin{tabular}{|c|c|c|}
\hline Plant & Location & Capacity \\
\hline \hline Shell & Iran & 110,000 \\
\hline Sasol & Iran & 30,400 \\
\hline NNPC & Nigeria & 12,500 \\
\hline Shell & Malaysia & 40,000 \\
\hline Syntroleum & Peru & 75,000 \\
\hline Shell-OPC & Qatar & 100,000 \\
\hline ExxonMobil-OPC & Qatar & 34,000 \\
\hline Sasol-OPC & Qatar & 30,000 \\
\hline PetroSA & South Africa & 50,000 \\
\hline ANGTL & U S A & 15,000 \\
\hline POVSA & Venezuela & \\
\hline Total Production 980,000 (bbl/day) & & \\
\hline
\end{tabular}

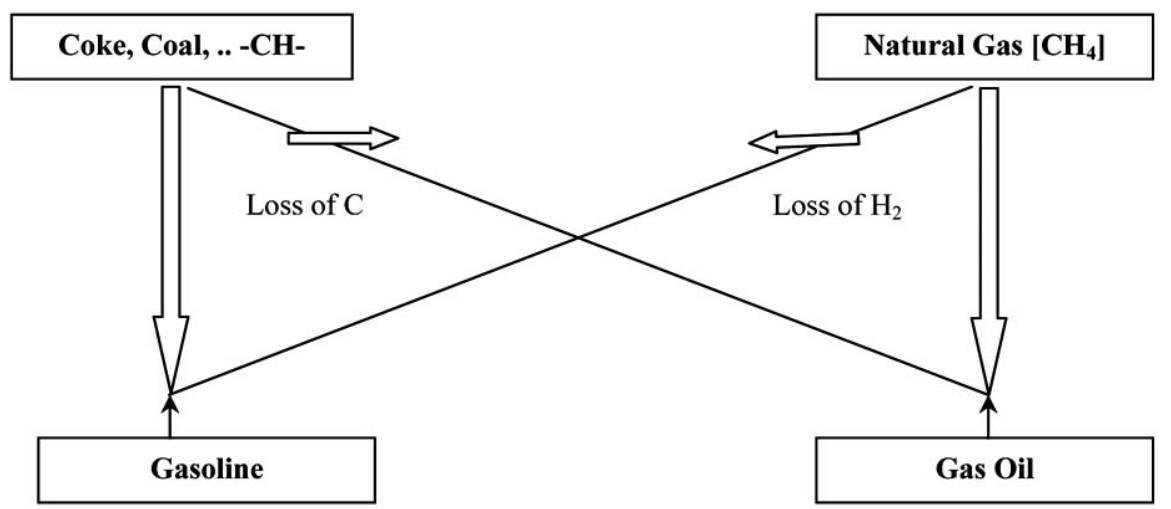

Fig. (5). Conversion routes as function of feed composition.

theoretical efficiency is possible. If the $\mathrm{C} / \mathrm{H}$ ratio of the feed/products differs substantially, rejection of $\mathrm{C}$ or Hydrogen- as the case may be - is inevitable and lower conversion efficiencies are the result. This is schematically illustrated in Fig. (5).

\section{REFERENCES}

[1] Abdel-Aal, H. K.; Shalabi, M. A. Non catalytic oxidation of sour natural gas versus catalytic steam reforming of sweet natural gas. Indian Eng. Chem. Res., 1996, 35, 1785-1787.

[2] Abdel-Aal, H. K.; Shalabi, M. A.; Al-Harbi, D. K.; Hakim, T. Simulation of the direct production of synthesis gas from sour natu- ral gas by none catalytic partial oxidation (ncpo), thermodynamics and stoichiometry. Indian Eng. Chem. Res., 1999, 38, 1069-1074.

[3] Bartholomew, C.H. Recent developments in fischer-tropsch catalysis. Catal. Lett., 1990, 7, 303-316.

[4] Singleton, A. H. Advances Make gas -to-liquids process competitive for remote locations. Oil Gas, 1997, 4, 68-72

[5] Soled, S.L.; Iglesia, E.; Fiato, R.A.; Baumgartner, J.E.; Vroman, H.; Miseo, S. Control of metal dispersion and structure by changes in the solid-state chemistry of supported cobalt fischer-tropsch catalysis. Topics Catal., 2003, 26, 101-109

[6] Thackeray, F. GTL in 2007, Petroleum Rev., 2003, 57, 18-19.

(C) Abdel-Kreem et al.; Licensee Bentham Open.

This is an open access article licensed under the terms of the Creative Commons Attribution Non-Commercial License (http://creativecommons.org/licenses/by-nc/3.0/) which permits unrestricted, non-commercial use, distribution and reproduction in any medium, provided the work is properly cited. 